\title{
KEWENANGAN BADAN PENGELOLAAN LINGKUNGAN HIDUP \\ DALAM MELAKUKAN MEDIASI KASUS LINGKUNGAN \\ (Studi kasus pada BPLH Kota Tarakan)
}

\author{
Wiwin Dwi Ratna F \\ Fakultas Hukum, Universitas Borneo Tarakan \\ Tarakan, Kalimantan Utara, Indonesia \\ winz fh@yahoo.co.id
}

\begin{abstract}
Amendments to the laws on local government undnagan impact on local government authority in running the affairs of government. For 10 years Indonesian running the regional autonomy system using Law No. 32 of 2004 on local government, and amendments thereto, for the moment the law declared invalid by the enactment of Law No. 23 Year 2014 on Regional Government, the State Gazette of the Republic of Indonesia Year 2014 No. 244, on October 2, 2014. in the Act governing the affairs of government that must be done by the central government, provincial government and local government district / city. Some affairs are regulated in more detail in the Government Regulation No. 18 Year 2016 concerning the Region, which regulates the scope of authority in dealing with government affairs. PP No. 1/2016 outlining the areas that must be held in an area with indicator, scale of values that can be found local work load. Environmental Management itself in Law number 23/2014 and Government Regulation No. $1 / 2016$ is a category / classified in the Mandatory government affairs unrelated to basic services.
\end{abstract}

Keywords: Local authorities, Environment, government affairs

\section{PENDAHULUAN}

\section{Latar Belakang}

Negara Kesatuan Republik Indonesia dibagi atas daerah provinsi dan daerah provisi dibagi atas daerah kabupaten dan Kota. Dalam pembagian wilayah tentunya akan berdampak pada pembagian kewenangan didalamnya. Pembagain kewenangan antara pemerintah pusat, pemerintah daerah provinsi dan pemerintah daerah kabupaten dan Kota, dilakukan berdasarkan asas 
desentralisasi dimana terdapat penyerahan urusan pemerintahan oleh permerintah pusat kepada daerah otonom berdasarkan asas Otonomi Daerah.

Sebagai negara yang dijuluki Archipelego State, Indonesia telah sejak awal menerapkan asas otonomi daerah dengan beragam polanya. pemerintah pusat sebagai pemerintahan yang memegang kekuasaan utama, sedangkan pemerintah daerah baik provinsi maupuan kabupaten dan Kota membantu pemerintahan pusat dalam mencapai tujuan Negara.

Dalam dinamika pelaksanaan sistem otonomi Daerah, Indonesia mengalami beberapa perubahan terhadap peraturan perundang-undangan tentang pemerintahan Daerah. Undang-undang Nomor 32 Tahun 2004 Tentang Pemerintah Daerah berlaku selama 10 tahun yang kemudian dicabut dan diganti dengan Undang-undang Nomor 23 Tahun 2014 tentang Pemerintahan Daerah. Dalam pergantian Undang0undang tersebut tentunya akan juga dilakukan penyesuaian dari yang Undang-undang yang lama ke Undnag-undang yang baru, meskipun dalam ketentuan penutup pada undang-undnag yang baru terdapat pasal yang menyatakan seluruh peraturan perundangan-undangan dinyatakan masih tetap berlaku sepanjang tidak bertentangan dan belum dinyatakan dicabut dan tidka berlaku.

UU nomor 23 Tahun 2014, lebih jelas mengatur mengenai Klasifikasi urusaan Pemerintahan sebagaimana Bab IV Urusan Pemerintahan, bagian kesatu, Klasifikasi Pemerintahan, pada pasal 9 menyatakan bahwa (1) urusan Pemerintahan terdiri atas urusan pemerintahan absolut, urusan pemerintahan konkuren, dan urusan pemerintahan umum.

Dari klasifikasi tersebut, maka dapat dilihat urusan-urusan dalam lingkup pemerintahan daerah terbagi-bagi menurut skala prioritas. Dan perubahan Undang-undang tentang pemerintahan daerah dimungkinkan akan ada pemerintahan daerah yang kehilangan dan atau bertambahan kewenangan yang diberikan oleh Undang-undang pemerintahan daerah yang baru, yakni 23/2014, demikian halnya dengan pengelolaan lingkungan hidup.

Isu-isu tentang perubahan iklim dan pemanasan global saat ini menjadi perhatian seluruh negara diduna, bahkan beberapa negara dan organisasiorganisasi dunia menyisihkan dananya untuk memperbaiki alam dan atau menjaga dan mempertahankan kelestariannya. Sehubungan akan hal tersebut, 
penelitian ini akan menganalisis kewenangan Badan Pengelolaan Lingkungan Hidup pada pemerintah daerah Kota Tarakan dalam melakukan mediasi Lingkungan.

\section{Rumusan Masalah}

Adapun yang menjadi rumusan masalah pada penelitian ini adalah :

1. Kewenangan Pengelolaan Lingkungan pada Pemerintah Daerah Kota

2. Standar Operasional Prosedur penanganan Kasus Lingkungan Hidup pada pemerintah Kota.

\section{Metode Penelitian}

Metode penelitian yang digunakan dalam penelitian ini adalah penelitian normatif, pada penelitian ini yang menjadi data primer berasal dari bahan-bahan hukum yang telah dinilai keakuratannya dan didukung dengan data sekunder dan tersier. Dalam menjawab permasalahan yang ada, peneliti menggunakan pendekatan perundang-undangan dan pendekatan konseptual. Kedua pendekatan ini dirasa mampu digunakan untuk menjawab permasalah yang ada.

\section{PEMBAHASAN}

\section{Gambaran Umum Kota Tarakan}

Pada tahun 1923 Pemerintah Hindia Belanda merasa perlu untuk menempatkan seorang Asisten Residen di pulau ini yang membawahi 5 (lima) wilayah yakni Tanjung Selor, Tarakan, Malinau, Apau Kayan dan Berau.

Pada masa pasca kemerdekaan, Pemerintah Republik Indonesia merasa perlu untuk merubah status kewedanan Tarakan menjadi Kecamatan Tarakan sesuai dengan Keppress Republik Indonesia Nomor 22 Tahun 1963.

Letak dan posisi yang strategis telah mampu menjadikan kecamatan Tarakan sebagai salah satu sentra Industri di wilayah Kalimantan Timur bagian utara sehingga Pemerintah perlu untuk meningkatkan statusnya menjadi Kota Administratif sesuai dengan Peraturan Pemerintah Nomor 47 Tahun 1981.

Status Kota Administratif kembali ditingkatkan menjadi Kotamadya berdasarkan Undang-Undang Republik Indonesia Nomor 29 Tahun 1997 yang peresmiannya dilakukan langsung oleh Menteri dalam Negeri pada tanggal 15 Desember 1997, sekaligus menandai tanggal tersebut sebagai Hari Jadi Kota Tarakan. 


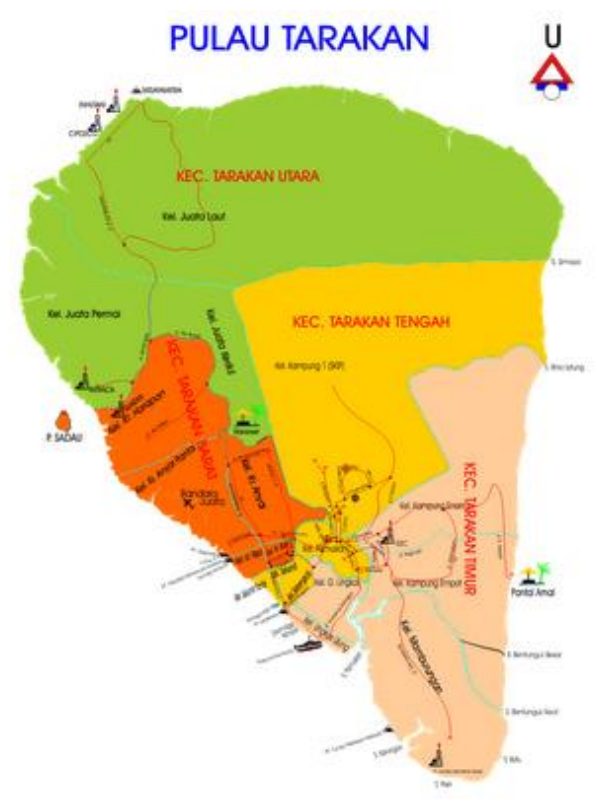

Tarakan merupakan sebuah pulau yang berada di utara pulau Kalimantan dan berbatasan dengan wilayah Negara Malaysia. Pulau Tarakan dengan luas daratan $250,80 \mathrm{~km}^{2}$ dan luas lautan $406,53 \mathrm{~km}^{2}$.

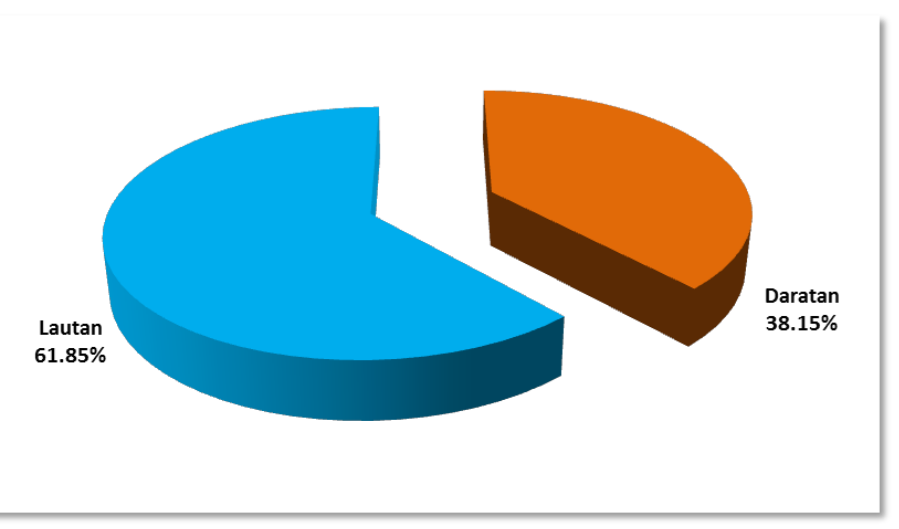

Grafik 2. Perbandingan Luas Wilayah Daratan dan Lautan, Kota Tarakan

Dengan luas yang hanya seluas 250,80 Kilo meter persegi, Tarakan memiliki jumlah penduduk yang cukup banyak, meskipun penyebaran tidak merata. Dikarenakan factor sejarah dan keadaan geografis, penduduk Tarakan sebagaian besar berada pada pesisir pantai. Berikut data jumlah penduduk Tarakan pertahun :

\begin{tabular}{|l|l|l|l|}
\hline Tahun & Laki-Laki & Perempuan & Jumlah \\
\hline
\end{tabular}




\begin{tabular}{|l|l|r|l|}
\multicolumn{1}{|l|}{$(1)$} & $(2)$ & \multicolumn{1}{|c|}{$(3)$} & \multicolumn{1}{l|}{$(4)$} \\
\hline 2010 & 102,700 & 93,300 & 196,000 \\
\hline 2011 & 106,800 & 97,100 & 203,900 \\
\hline 2012 & 111,100 & 101,000 & 212,100 \\
\hline 2013 & 115,300 & 104,900 & 220,200 \\
\hline 2014 & 119,000 & 108,200 & 227,200 \\
\hline
\end{tabular}

Tarakan dalam angka menyatakan bahwa pertumbuhan penduduk Tarakan cukup pesat, Pemerintah Kota Tarakan harus mampu mengimbangi pertumbuhan masyakarakatnya dengan kelengkapan - kelengkapan aparat dan kaidah hukum yang dapat mengatur kehidupan bermasyarakat.

Hal ini dipandang penting untuk dilakukan, karena semakin berkembangnya jumlah penduduk, maka akan berdampak pada kebutuhan akan alam yang semakin meluas.

Kebutuhan akan pemukiman, pertanian, dan kebutuhan-kebutuhan lainnya yang jika tidak dijaga akan menghilangkan keutuhan ekosistem dan berkurangnya ruang terbuka hijau bahkan dapat berdampak pada terambahnya hutan menjadi lahan yang digunakan untuk kebutuhan primer maupun sekunder masyarakat.

Berikut angka pertumbuhan penduduk Tarakan yang ditunjukan dengan grafik sehingga dapat memperjelas peningkatan dan penurunan pertumbuhan penduduk Tarakan.

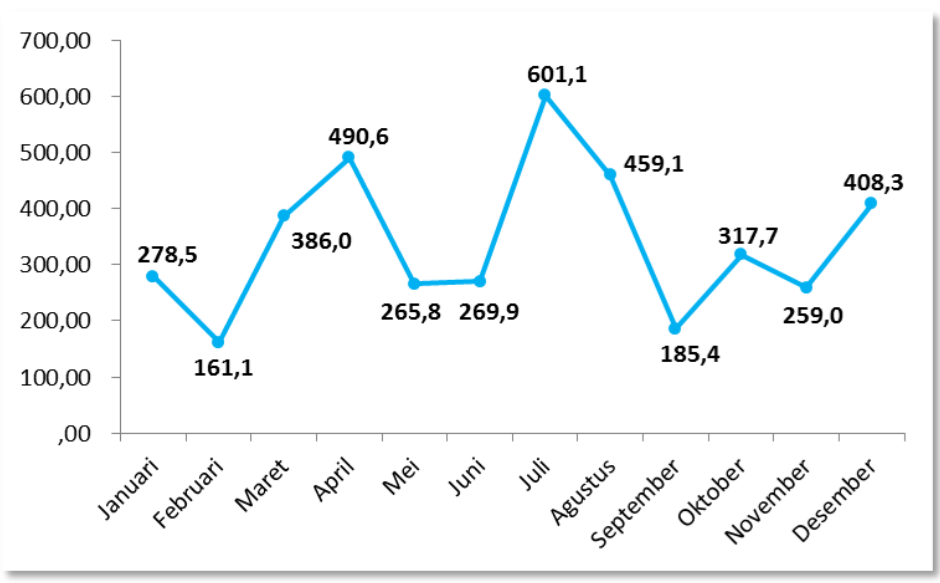

Grafik. Pertumbuhan Pendudukan Tarakan 
Kelestarian Lingkungan ini dapat dicapai apabila dibarengi dengan pengelolaan lingkungan hidup melalui pengelolaan dan pelaksanaan undangundang lingkungan hidup ${ }^{1}$ Program perindustrian yang cepat dan tidak diikuti dengan pengelolaan lingkungan hidup juga dapat mengakibatkan bencana alam, seperti yang terjadi diberbagai negara yang sedang membangun, misalnya pengembangan wilayah yang tidak baik di Malaysia dapat meningkatkan keurgian yang diakibatkan oleh banjir². Tidak dapat dipungkiri, bahwasannya pembangunan memang merupakan salah satu sebab terjadinya perubahan lingkungan hidup. Penghilangan hutan dan atau beberapa tumbuhan hijau untuk dijadikan perubahan dan atau bangunan-bangunan menjadikan perubahan ekosistem lingkungan hidup.

Pencemaran Lingkungan hidup adalah masuk atau dimasukkannya makhluk hidup, zat, energi, dan/atau komponen lain ke dalam lingkungan hidup oleh kegiatan manusia sehingga melampaui baku mutu lingkungan hidup yang telah ditetapkan. Pasal 1 ayat 14 UU nomor 32 tahun 2009 tentang pengelolaan lingkungan hidup.

Pencemaran lingkungan dapat terjadi pada lingkungan air, tanah, dan udara. Sebagaimana Peraturan Pemerintah Nomor 20 tahun 1990 tentang Pengendalian Pencemaran Air, pasal 1 angka 2 menyebutkan tentang definisi pencemaran air yakni "pencemaran air adalah masuknya atau dimasukkannya mahluk hidup, zat, energi dan atau komponen lain ke dalam air oleh kegiaan manusia sehingga kualitas air turun sampai ke tingkat tertentu yang menyebabkan air tidak berfungsi lagi sesuai dengan peruntukannya”.

Lebih lanjut dapat dilihat pengertian mengenai Pemcemaran Udara yang terdapat dalam pasal 1 angka 1, Peraturan Pemerintah Nomor 41 Tahun 1999 tentang Pengendalian Pencemaran Udara, yang menyatakan bahwa pencemaran udara adalah masukknya atau dimasukkannya zat, energi, dan/atau komponen lain ke dalam udara ambien oleh kegiatan manusia, sehingga mutu udara ambien turun sampai ke tingkat tertentu yang menyebabkan udara ambien tidak dapat memenuhi fungsinya.

\footnotetext{
${ }^{1}$ Firestone, J. 2002, Agency governance and enforcement: the influence of mission on environmental decisionmaking, Journal of police analysis dan Pengurusant 21(3); 409-426

${ }^{2}$ Chan, N.W., Parker D.J. Response to dynamic Flood Hazard Factors in Peninsular Malaysia, The Geographical Journal 162 (part 3); 1996. H. 313-325
} 


\section{Kewenangan BPLH dalam menangani Kasus Lingkungan Hidup}

Undang-undang Lingkungan hidup, terbit sebelum diundangkannya Undang-undang Nomor 23 Tahun 2014 tentang pemerintahan daerah, diundangkan pada Lembaran Negara Republik Indonesia Tahun 2014 Nomor 244, pada tanggal 2 oktober 2014. Dengan terbitnya UU nomor 23 tahun 2014, maka UU Nomor 32 Tahun 2004 dinyatakan dicabut dan tidak berlaku, sebagaimana tercantum dalam pasal 409 UU No 23 Tahun 2014. Namun demikian Undang-undang Nomor 32 tahun 2009 tentang Perlindungan dan Pengelolaan Lingkungan Hidup masih tetap dinyatakan berlaku. Sebagaimana pasal 408 yang menjelaskan bahwa semua peraturan perundang-unangan yang berkaitan dengan penyelenggaran Pemerintahan Daerah dinyatakan masih tetap berlaku sepanjang belum diganti dan tidak bertentangan dengan ketentuan dalam undang-undang ini. Pasal ini dapat diterapkan bahwa kewenangan pemerintahan daerah kabupaten/kota yang terdapat dalam Undang-undang Nomor 32 tahun 2009 tentang Perlindungan dan Pengelolaan Lingkungan Hidup masih dapat digunakan sebagai dasar hukum.

Dalam UU Pemerintahan daerah, Lingkungan Hidup merupakan salah satu urusan Pemerintahan Wajib yang tidak berkaitan dengan Pelayanan dasar.

Undang-undang Pengelolaan Lingkungan hidup dalam Bab IX tentang Tugas dan Wewenang Pemerintah dan Pemerintah Daerah, pasal 63 ayat 3 menyebutkan bahwa Dalam perlindungan dan pengelolaan lingkungan hidup, pemerintah kabupaten/kota bertugas dan berwenang :

a. menetapkan kebijakan tingkat kabupaten/kota;

b. menetapkan dan melaksanakan KLHS tingkat kabupaten/kota;

c. menetapkan dan melaksanakan kebijakan mengenai RPPLH kabupaten/kota

d. menetapkan dan melaksanakan kebijakan mengenai amdal dan UKL-UPL;

e. menyelenggarakan inventarisasi sumber daya alam dan emisi gas rumah kaca pada tingkat kabupaten/kota;

f. mengembangkan dan melaksanakan kerja sama dan kemitraan;

g. mengembangkan dan menerapkan instrument lingkungan hidup;

h. memfasilitasi penyelesaian sengketa; 
i. melakukan pembinaan dan pengawasan ketaatan penanggungjawab usaha dan/atau kegaitan terhadap ketentuan perizinan lingkungan dan peraturan perundang-undangan;

j. melaksanakan standar pelayanan minimal;

k. melaksanakan kebijakan mengenai tata cara pengakuan keberadaan masyarakat hukum adat, kearifan local, dan hak masyarakat hukum adat yang terkait dengan perlindungan dan pengelolaan lingkugan hidup pada tingkat kabupaten/kota;

l. mengelola informasi lingkungan hidup tingkat kabupaten/kota;

m. mengembangkan dan melaksanakan kebijakan system informasi lingkugan hidup tingkat kabupaten/kota;

n. memberikan pendidikan, pelatihan, pembinaan dan penghargaan;

o. menerbitkan izin lingkungan pada tingkat kabupaten/kota;

p. melakukan penegaran hukum lingkungan hidup pada tingkat kabupaten/kota.

Sebagaimana pasal tersebut, bahwa pemerintah Kabupaten Kota memiliki kewenangan untuk memfasilitasi penyelesaian sengketa lingkunga yang terjadi diwilayah kerjanya.

Kewenangan yang diperoleh oleh Pemerintah kabupaten/Kota sejalan dengan asas Dekonsentrasi pada Undang-undang 32/2014, yang menyatakan bahwa Pelimpahan sebagain urusan pemerintahan yang menjadi kewenangan pemerintah pusat kepada gubernur sebagai wakil pemerintah Pusat, kepada instansi vertikal di wilayah tertentu, dan/atau kepada gubernur dan bupati/walikota sebagai penanggungjawab urusan pemerintahan umum.

Dalam lampiran Undang-undang Nomor 23 Tahun 2014, Pembagaian Urusan Pemerintahan Konkuren ataran Pemerintah Pusat dan Daerah Provinsi dan Daerah kabupaten/Kota, mengamanatkan kepada Pemerintah kabupaten/Kota untuk melakukan Penyelesaian Pengaduan masyarakat di bidang PPLH pada sub Bidang Pengaduan Lingkungan Hidup.

Peraturan Pemerintah Republik Indonesia Nomor 18 Tahun 2016 tentang Perangkat Daerah, Pasal 37 ayat 4 Menjelaskan bahwa Urusan Pemerintahan Wajib yang tidak berkaitan dengan pelayanan dasar, terdiri atas:

a. tenaga kerja; 
b. pemberdayaan perempuan dan perlindungan anak;

c. pangan;

d. pertanahan;

e. lingkungan hidup;

f. administrasi kependudukan dan pencatatan sipil;

g. pemberdayaan masyarakat dan Desa;

h. pengendalian penduduk dan keluarga berencana;

i. perhubungan;

j. komunikasi dan informatika;

k. koperasi, usaha kecil, dan menengah;

l. penanaman modal;

m. kepemudaan dan olah raga;

n. statistik;

o. persandian;

p. kebudayaan;

q. perpustakaan; dan

r. kearsipan.

Dalam pasal tersebut dijelaskan bahwa Lingkungan hidup merupakan urusan pemerintahan wajib, yang dapat diartikan bahwa menajdi wajib diselenggarakan oleh Daerah sebagaimana pasal 1 ayat 10 Peraturan Pemerintah Nomor 18 Tahun 2016 tentang Perangkat Daerah.

Konsekuensi adanya UU 32/2014, didalamnya mengatur tentang pembagian urusan, yang diperjelas dengan adanya PP no 18/2016, maka pemerintah daerah kabupaten/Kota harus memperhatikan beberapa indikator capaian beban kerja untuk dapat menentukan nomenklatur Dinas atau badan di dalam lingkungan pemerintahannya. Sehingga pemeritnah daerah kabupaten / Kota terlebih dahulu harus dapat menilai dan menentukan skala nilai, kemudian dikalikan dengan bobot dan kemudian menghasilkan Skor. Dari skor tersebut dapat dilakukan penetapan intensitas urusan pemerintahan dan beban kerja perangkat daerah. Dan berdasarkan hasil perhitungan tersebut didapati beberapa kriteria, yakni : 
1. Total skor kurang dari atau sama dengan 300, merupakan isntensitas sangat kecil dan diwadahi dalam perangkat Daerah setingkat seksi/Subbidang;

2. Total skor lebih dari 300 samapi dengan 400, merupakan isntensitas sangat kecil dan diwadahi dalam perangkat Daerah setingkat bidang;

3. Total skor lebih dari 401 samapi dengan 600, merupakan isntensitas kecil dan diwadahi dalam perangkat Daerah tipe C;

4. Total skor lebih dari 601 samapi dengan 800, merupakan isntensitas sedang dan diwadahi dalam perangkat Daerah tipe B;

5. Total skor lebih dari 800, merupakan isntensitas besar dan diwadahi dalam perangkat Daerah tipe A;

Mengenai indikator pemetaan intensitas urusan pemerintahan dan Penentuan Beban Kerja Perangkat Daerah Pemerintah Kabupaten/Kota, menyebutkan bahwa :

K. URUSAN PEMERINTAHAN BIDANG LINGKUNGAN HIDUP

\begin{tabular}{|c|l|c|c|c|}
\hline NO & \multicolumn{1}{|c|}{ INDIKATOR \& KELAS INTERVAL } & $\begin{array}{c}\text { SKALA } \\
\text { NILAI }\end{array}$ & $\begin{array}{c}\text { BOBOT } \\
\text { (\%) }\end{array}$ & SKOR \\
\hline $\mathbf{1}$ & \multicolumn{1}{|c|}{$\mathbf{2}$} & $\mathbf{3}$ & $\mathbf{4}$ & $\mathbf{5}$ \\
\hline 1 & Jumlah usaha/kegiatan penghasi1 & & & \\
& limbah B3 & 200 & & \\
& a. $\leq 10$ & 400 & & 30 \\
& b. $11-50$ & 600 & 15 & 60 \\
& c. $51-120$ & 800 & & 120 \\
& d. $121-200$ & 1.000 & & 150 \\
\hline
\end{tabular}




\begin{tabular}{|c|c|c|c|c|}
\hline NO & INDIKATOR \& KELAS INTERVAL & $\begin{array}{l}\text { SKALA } \\
\text { NILAI }\end{array}$ & $\begin{array}{c}\text { BOBOT } \\
(\%)\end{array}$ & SKOR \\
\hline 1 & 2 & $\mathbf{3}$ & 4 & 5 \\
\hline 2 & $\begin{array}{l}\text { Jumlah TPS } \\
\text { a. } \leq 30 \\
\text { b. } 31-60 \\
\text { c. } 61-90 \\
\text { d. } 91-120 \\
\text { e. }>120\end{array}$ & $\begin{array}{c}200 \\
400 \\
600 \\
800 \\
1.000\end{array}$ & 15 & $\begin{array}{c}30 \\
60 \\
90 \\
120 \\
150\end{array}$ \\
\hline 3 & $\begin{array}{l}\text { Jumlah bank sampah } \\
\text { a. } \leq 15 \\
\text { b. } 16-30 \\
\text { c. } 31-45 \\
\text { d. } 46-60 \\
\text { e. }>60\end{array}$ & $\begin{array}{c}200 \\
400 \\
600 \\
800 \\
1.000\end{array}$ & 15 & $\begin{array}{c}30 \\
60 \\
90 \\
120 \\
150\end{array}$ \\
\hline 4 & $\begin{array}{l}\text { Jumlah Dokumen Lingkungan yang } \\
\text { dinilai (AMDAL, UKL/UPL, dan SPPL) } \\
\text { yang izinnya dikeluarkan oleh } \\
\text { pemerintah kabupaten/kota } \\
\text { a. } \leq 10 \\
\text { b. } 11-30 \\
\text { c. } 31-50 \\
\text { d. } 51-100 \\
\text { e. }>100\end{array}$ & $\begin{array}{c}200 \\
400 \\
600 \\
800 \\
1.000\end{array}$ & 20 & $\begin{array}{c}40 \\
80 \\
120 \\
160 \\
200\end{array}$ \\
\hline 5 & $\begin{array}{l}\text { Jumlah objek yang harus dilakukan } \\
\text { pemantauan kualitas lingkungan } \\
\text { sesuai ketentuan yang berdampak } \\
\text { dalam satu kabupaten/kota } \\
\text { a. } \leq 5 \\
\text { b. } 6-15 \\
\text { c. } 16-20 \\
\text { d. } 21-25 \\
\text { e. }>25\end{array}$ & $\begin{array}{c}200 \\
400 \\
600 \\
800 \\
1.000\end{array}$ & 15 & $\begin{array}{c}30 \\
60 \\
90 \\
120 \\
150\end{array}$ \\
\hline
\end{tabular}

Dari penghitungan indikator tersebut, maka dapat dilihat beban kerja perangkat daerah. Meskipun demikian, kesulitan geografis jug amenjadi salah satu faktor pengkalian / penghitungan indikator dari variable umum dan variable teknis.

\section{Standar Operasional Prosedur Penangan Kasus pada BPLH Kota Tarakan}

Kasus pencemaran lingkungan merupakan kasus yang membutuhkan waktu dan perhatian lebih dibandingkan dengan kasus-kasus lainnya. Hal ini dikarenakan kasus lingkungan hidup dapat sangat berpengaruh pada ekosistem alam disekitarnya, dan memungkinkan akan terjadi hilang atau putusnya satu rantai siklus dalam rantai makanan/ ekosistem di dalam alam. Selain dari itu, kasus lingkungan hidup juga harus secepatnya dilakukan pengambilan sample 
(contoh) area/wilayah/objek tercemar. Keterlambatan pengambilan sample akan berdampak pada hilangnya alat bukti pada kasus pencemaran lingkungan.

Untuk itu Badan Pengeleolaan Lingkungan Hidup Kota Tarakan saat ini telah memiliki Standar Operasional Prosedur penanganan kasus lingkungan hidup di wilayah Kota Tarakan. Sehingga dalam setiap penanganan kasus lingkungan hidup, Badan Lingkungan Hidup Tarakan menggunakan alur dan system yang jelas, hal tersebut dapat mempermudah pelacakan serta penanganan yang tepat waktu, hemat dan efisien. BPLH melakukan penanganan terhadap kasus lingkungna hidup dapat berasal dari pengaduan yang diadukan oleh orang perorangan, Lembaga masyarakat, ketua RT, kelurahan, kecamatan ataupun siapa saja yang melihat dan atau mengalami terjadinya kasus pencemaran lingkungan. Namun tak jarang, BPLH sendiri yang saat melakukan pengawasan menemukan kasus pencemaran lingkungan hidup. Untuk itu BPLH sangat membutuhkan partisipasi dari kalangan masyarakat untuk dapat meloporakan disetiap terjadi atau bahkan indikasi terjadinya pencemaran dan atau perusakan lingkungan.

Setelah adanya laporan/pengaduan yang berasal dari pengadu, selajutnya berada pada tahap Klasifikasi/telaahan aduan. Pada tahapan ini, klasifikasi/telaah pengaduan dilakukan oleh tim penanganan pengaduan, dengan jangka waktu maksimal 7 hari sejak diterimanya pengaduan terhadap kasus pencemaran lingkungan hidup. Pada tahapan proses ini, akan dilakukan telaahan apakah kasus yang dilaporan oleh pelapor adalah benar kasus atau terindikasi berupa pencemaran/kerusakan lingkungan hidup atau tidak, jika hasil telaahan menunjukkan bahwa laporan/aduan tersebut bukan terkategori kasus kerusakan/pencemaran lingkungan hidup, maka kasus tersebut akan diserahkan ke instansi terkait yang memiliki kaitan paling erat dari kasus tersebut, dan tim BPLH akan menyampaikan dan menjelaskan kepada pihak pengadu/pelapor bahwa kasus yang diadukan bukan merupakan kasus pencemaran/perusakan lingkugan hidup dan telah di teruskan kepada instansi terkait.

Namun jika dari hasil klarifikasi/telaahan ditemukannya indikasi perusakan/pencemaran lingkungan hidup, maka proses penangangan kasus akan berlanjut pada tahapan Verifikasi. 
Tahapan Verifikasi ini dibatasi maksimal 7 hari, pada tahapan ini, pos pengaduan akan melakukan verifikasi terhadap laporan/pengaduan pencemaran lingkungan. Pada tahapan verifikasi ini, dilakukan pemisahan/ pengelompokanterhadap yang terjadi pada laporan/pengaduan tersebut.

Adapun pengelompokan dapat dilakukan sebagai berikut :

1. Terjadi pelanggaran administrasi, namun tidak terjadi pencemaran lingkungan.

2. Terjadi Pelanggaran administrasi, dan terjadi pencemaran lingkungan .

3. Terjadi pencemaran, dan berakibat pada kematian dan atau luka berat.

Dari tahapan verifikasi tersebut, kemudian ditindak lanjuti oleh BPLH sesuai dengan pengelompokkannya, yakni tahapan upaya tindak lanjut pencemaran. Dalam hal penindaklanjutan, BPLH bisa menjatuhkan sanksi administrasi. 


\section{STANDART OPERATIONAL PROCEDURE}

POS PENGADUAN LINGKUNGAN HIDUP

BADAN PENGELOLAAN LINGKUNGAN HIDUP KOTA TARAKAN

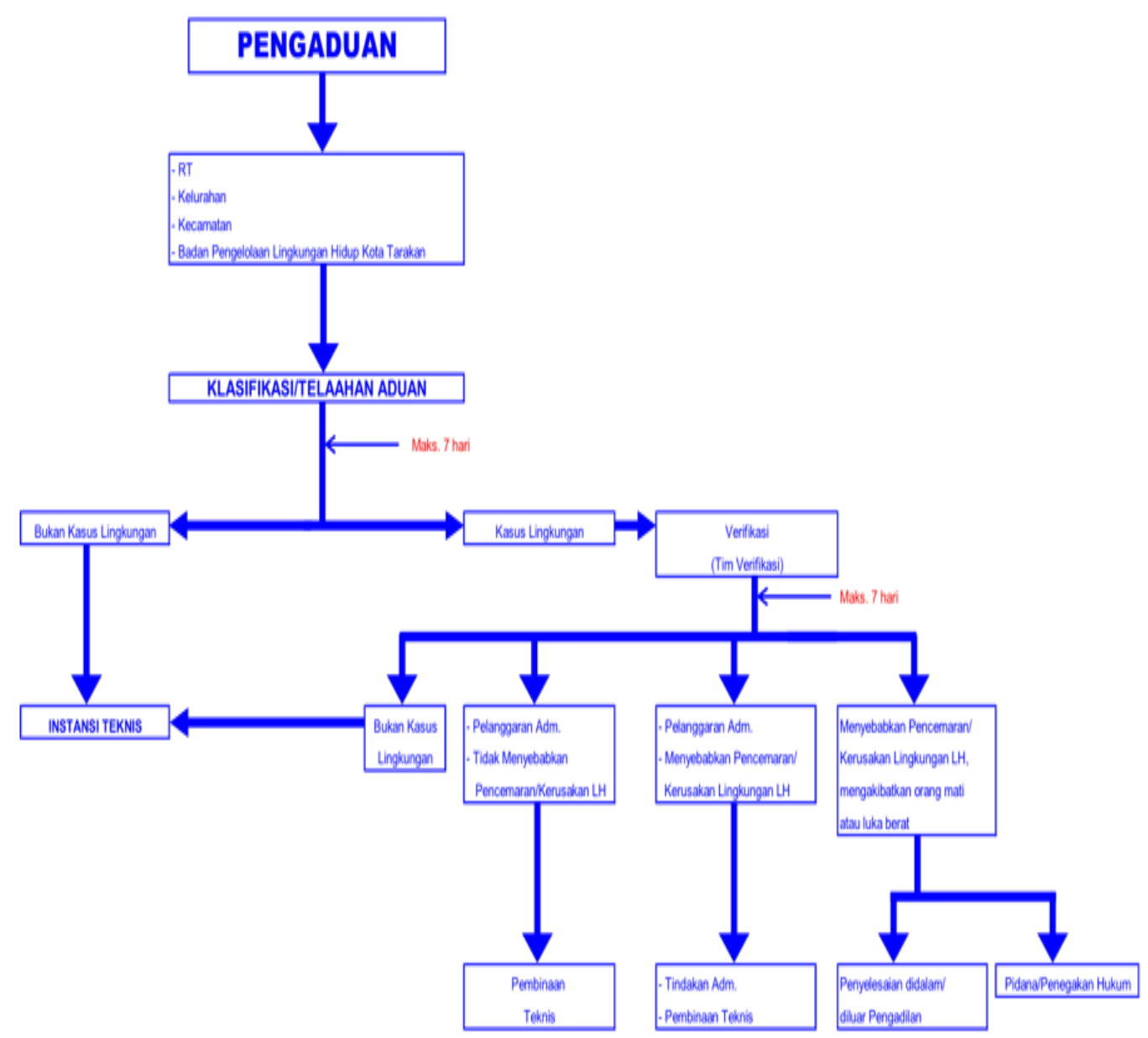

Sebagaimana bagan tersebut, maka penangan terhadap pencemaran lingkungan hidup di kota Tarakan dapat sesegera mungkin ditindaklanjuti.

\section{PENUTUP}

\section{Kesimpulan}

Bahwa meski terdapat perubahan terhadap peraturan Perundang-undangan tentang Pemerintahan daerah yakni UU no 32 Tahun 2004 dicabut dan dinyatakan tidak berlaku dengan adanya UU nomor 23 Tahun 2016 tentang Pemerintahan Daerah serta adanya Peraturan Pemerintah Nomor 18 Tahun 
2016 tentang Perangkat Daerah, namun lingkungan Hidup merupakan urusan wajib yang tidak berkaitan dengan pelayanan dasar yang harus tetap ada di pemerintah daerah kabupaten / kota. Hanya saja pengelolaan lingkungan ditingkat kabupaten / Kota harus terlebih dahulu dinilai berdasarkan indikator beban kerja sehingga dapat dinilai dan ditetapkan dalam bentuk lembaga Badan atau dinas atau bahkan hanya sebagai subbidang atau cukup dengan bidang.

Bahwa penanganan kasus lingkungan hidup pada di Kota Tarakan, telah dilakukan semaksimal mungkin, dan bahkan lingkungan hidup kota Tarakan telah memiliki Manual prosedur penanganan kasus/sengketa lingkungan.

\section{Saran}

Bahwa pemerintah daerah sesegera mungkin melakukan penghitangan skor terhadap beban kerja pada urusan pemerintahan, sehingga dapat meminimalisasi pengeluaran terhadap keuangan daerah dalam hal ini tunjangan jabatan pada instansi-instansi sebagaimana yang tertuang dalam Peraturan Pemerintah nomor 18 Tahun 2016.

\section{DAFTAR PUSTAKA}

Andi Hamzah, Jur, Penegakan Hukum Lingkungan, cetakan pertama., Sinar Grafika., Bandung, 2005

Arief Hidayat dan Adji Samekto, Hukum Lingkungan dalam presfektif nasional dan Global, UndipPress, Semarang, 1990.

Amiruddin dan Zainal Asikin, Pengantar Metode Penelitian Hukum, PT. Raja Grafindo Persada, Jakarta, 2003.

Hans Kelsen, Teori Umum Tentang Hukum dan Negara, Nusa Media, Bandung, 2014.

Jimly Assyddiqie, Perihal Undang-Undang, Konpress, Jakarta, 2006.

Koesnadi Hardjosoemantri, Hukum Tata Lingkungan, Cetakan Kedelapan belas, Gajahmada University Press, Jogjakarta. 2005.

R. Soeroso, Pengantar Ilmu Hukum, Sinar Grafika, Jakarta, 2011.

Safri Nugraha, dkk, Hukum Administrasi Negara, Universitas Indonesia, Depok, 2007.

Sidharta, B. Arief, Meuwissen Tentang Pengembanan Hukum, Ilmu Hukum, Teori Hukum, dan Filsafat Hukum, Cet. Pertama, PT. Refika Aditama, Bandung, 2007. 